\title{
High-throughput mutational analysis of TORIA in primary dystonia
} Jianfeng Xiao' ${ }^{1}$, Robert W Bastian ${ }^{2}$, Joel S Perlmutter ${ }^{3}$, Brad A Racette ${ }^{3}$, Samer D Tabbal ${ }^{3}$, Morvarid Karimi ${ }^{3}$, Randal C Paniello ${ }^{3}$, Andrew Blitzer ${ }^{4}$, Sat Dev Batish ${ }^{5}$, Zbigniew K Wszolek ${ }^{6}$, Ryan J Uitti ${ }^{6}$, Peter Hedera ${ }^{7}$, David K Simon' ${ }^{8}$, Daniel Tarsy ${ }^{8}$, Daniel D Truong', Karen P Frei ${ }^{9}$, Ronald F Pfeiffer ${ }^{1}$, Suzhen Gong ${ }^{1}$, Yu Zhao ${ }^{1}$ and Mark S LeDoux*1

Address: ${ }^{1}$ Departments of Neurology and Anatomy \& Neurobiology, University of Tennessee Health Science Center, Memphis, TN, USA, ${ }^{2}$ Bastian Voice Institute, Downers Grove, IL, USA, ${ }^{3}$ Department of Neurology, Washington University School of Medicine, St. Louis, MO, USA, ${ }^{4}$ New York Center for Voice and Swallowing Disorders, New York, NY, USA, ${ }^{5}$ Athena Diagnostics, Inc., Worcester, MA, USA, ${ }^{6}$ Department of Neurology, Mayo Clinic, Jacksonville, FL, USA, ${ }^{7}$ Department of Neurology, Vanderbilt University, Nashville, TN, USA, ${ }^{8}$ Department of Neurology, Beth Israel Deaconess Medical Center and Harvard Medical School, Boston, MA, USA and 'Parkinson's \& Movement Disorder Institute, Fountain Valley, CA, USA

Email: Jianfeng Xiao - jianfengxiao@gmail.com; Robert W Bastian - robert.bastian@bastianvoice.com; Joel S Perlmutter - joel@npg.wustl.edu; Brad A Racette - racetteb@neuro.wustl.edu; Samer D Tabbal - tabbals@neuro.wustl.edu; Morvarid Karimi - morvaridk@npg.wustl.edu; Randal C Paniello - paniellor@ent.wustl.edu; Andrew Blitzer - Ab1136@aol.com; Sat Dev Batish - dev.batish@athenadiagnostics.com; Zbigniew K Wszolek - Wszolek.Zbigniew@mayo.edu; Ryan J Uitti - uitti@mayo.edu; Peter Hedera - peter.hedera@vanderbilt.edu; David K Simon - dsimon1@bidmc.harvard.edu; Daniel Tarsy - dtarsy@bidmc.harvard.edu; Daniel D Truong - dtruong@pmdi.org; Karen P Frei - kfrei@pmdi.org; Ronald F Pfeiffer - rpfeiffer@utmem.edu; Suzhen Gong - sgong@utmem.edu; Yu Zhao - yzhao3@utmem.edu; Mark S LeDoux* - mledoux@utmem.edu

* Corresponding author

Published: II March 2009

BMC Medical Genetics 2009, 10:24 doi:10.1 186/147I-2350-10-24
Received: 7 December 2008

Accepted: II March 2009

This article is available from: http://www.biomedcentral.com//47I-2350/I0/24

(c) 2009 Xiao et al; licensee BioMed Central Ltd.

This is an Open Access article distributed under the terms of the Creative Commons Attribution License (http://creativecommons.org/licenses/by/2.0), which permits unrestricted use, distribution, and reproduction in any medium, provided the original work is properly cited.

\begin{abstract}
Background: Although the c.904_906delGAG mutation in Exon 5 of TORIA typically manifests as early-onset generalized dystonia, DYTI dystonia is genetically and clinically heterogeneous. Recently, another Exon 5 mutation (c.863G>A) has been associated with early-onset generalized dystonia and some $\triangle \mathrm{GAG}$ mutation carriers present with late-onset focal dystonia. The aim of this study was to identify TORIA Exon 5 mutations in a large cohort of subjects with mainly nongeneralized primary dystonia.
\end{abstract}

Methods: High resolution melting (HRM) was used to examine the entire TORIA Exon 5 coding sequence in 1014 subjects with primary dystonia (422 spasmodic dysphonia, 285 cervical dystonia, 67 blepharospasm, 41 writer's cramp, 16 oromandibular dystonia, 38 other primary focal dystonia, I I 2 segmental dystonia, 16 multifocal dystonia, and 17 generalized dystonia) and 250 controls (I50 neurologically normal and 100 with other movement disorders). Diagnostic sensitivity and specificity were evaluated in an additional 8 subjects with known $\triangle$ GAG DYTI dystonia and 88 subjects with $\triangle \mathrm{GAG}$-negative dystonia.

Results: HRM of TORIA Exon 5 showed high (I00\%) diagnostic sensitivity and specificity. HRM was rapid and economical. HRM reliably differentiated the TORIA $\triangle$ GAG and c.863G >A mutations. Melting curves were normal in 250/250 controls and I0I2/I0I4 subjects with primary dystonia. The two subjects with shifted melting curves were found to harbor the classic $\triangle$ GAG deletion: I) 
a non-Jewish Caucasian female with childhood-onset multifocal dystonia and 2) an Ashkenazi Jewish female with adolescent-onset spasmodic dysphonia.

Conclusion: First, HRM is an inexpensive, diagnostically sensitive and specific, high-throughput method for mutation discovery. Second, Exon 5 mutations in TORIA are rarely associated with non-generalized primary dystonia.

\section{Background}

Dystonia is a syndrome of sustained muscle contractions, frequently causing twisting and repetitive movements, or abnormal postures [1]. Dystonia can be classified by etiology (primary or secondary), age of onset (childhoodonset [0-12 yrs], adolescent-onset [13-20 yrs], or lateonset [>20 yrs]), and anatomical distribution (focal, segmental, multifocal, hemidystonia, or generalized) [1-4]. Primary generalized dystonias usually begin in childhood or adolescence, whereas focal dystonias typically present during adult life. Primary dystonia includes syndromes in which dystonia is the sole phenotypic manifestation, with the exception that tremor may be present as well.

In most neurology subspecialty practices, the vast majority of patients with dystonia are adults with primary focal or segmental disease. Genetic factors likely play a major role in late-onset primary dystonia since $8-27 \%$ of patients with primary late-onset dystonia have one or more family members affected with dystonia [5-9] and several of the primary dystonias inherited in Mendelian fashion (DYT1, DYT5, DYT6, DYT11, and DYT12) begin focally, show incomplete penetrance and exhibit variable anatomical expressivity [10-12]. These facts suggest that sporadic late-onset dystonia, much like Parkinson's disease, is a complex disorder with contributions from multiple genes and environmental factors. Candidate gene studies have been successful in several late-onset neurological disorders, particularly Parkinson's disease, and may be fruitful in primary dystonia. Late-onset sporadic dystonia could be associated with a number of distinct mutations of low penetrance.

The $\triangle$ GAG (c.904_906delGAG) mutation in Exon 5 of TOR1A is characteristically associated with early-onset generalized dystonia [13]. Although infrequent, the DYT1 $\triangle$ GAG mutation has also been associated with late-onset focal, segmental, and multifocal dystonia [14-19]. Another mutation in Exon 5 of TOR1A (c.863G>A) has been described in a female patient with severe childhood-onset generalized dystonia [20]. The G>A transition in Exon 5 results in exchange of an arginine for glutamine. In contrast to the DYT1 $\triangle$ GAG mutation, analysis of late-onset dystonia cases for the $c .863 \mathrm{G}>\mathrm{A}$ mutation has not been described to date. Two additional mutations have been described in Exon 5, the terminal exon of TOR1A. Leung and colleagues [21] reported a patient with early-onset dys- tonia and myoclonus who harbored an 18-bp deletion in Exon 5 which should eliminate 6 amino acids near the carboxy terminus of torsinA (Phe323_Tyr328del), including a putative phosphorylation site. The causality of the 18-bp deletion is unclear since the same subject was subsequently found to have an SGCE mutation [22]. As described in another study, a novel out-of-frame 4-bp deletion (c.934_937delAGAG) found in a putatively healthy blood donor should result in an alteration of amino acids starting at position 312 with a premature stop at position 325 (E312/Stop325) in the carboxy terminus of torsinA [18].

To help address the role of the TOR1A gene in non-generalized primary dystonia, we used high resolution melting (HRM) to examine the entire TOR1A Exon 5 coding sequence in a large cohort of patients with non-generalized dystonia. HRM has been shown to be a fast and accurate, closed-tube, post-PCR mutation scanning technique that monitors the progressive change in fluorescence caused by the release of an intercalating DNA dye from DNA duplexes as they are denatured by minor increases in temperature [23]. Our results indicate that mutations in Exon 5 of TOR1A are rare in non-generalized primary dystonia.

\section{Methods \\ Subjects}

All human studies were performed in accordance with institutional review board guidelines and all subjects gave informed consent. Subjects with dystonia and neurologically-normal controls were acquired from outpatient clinics at participating institutions (University of Tennessee Health Science Center, Bastian Voice Institute, Washington University School of Medicine in St. Louis, New York Center for Voice and Swallowing Disorders, Mayo Clinic Jacksonville, Beth Israel Deaconess Medical Center, Vanderbilt University and the Parkinson's \& Movement Disorder Institute) and support group meetings of the National Spasmodic Dysphonia Association (NSDA), National Spasmodic Torticollis Association (NSTA), Benign Essential Blepharospasm Research Foundation (BEBRF), Dystonia/Spasmodic Torticollis, and Dystonia Medical Research Foundation (DMRF). All subjects with dystonia acquired at support group meetings were examined by M.S.L. Subjects with Parkinson's disease and other movement disorders were acquired from the clinics of M.S.L. and R.F.P. Clinical diagnoses and classifications were 
made by means of history and examination by one or more neurologists and/or neurolaryngologist at each institution. Neurologically-normal control subjects were defined as individuals with no personal or first-degree family history of neurological disease. In addition, all control subjects acquired at the University of Tennessee Health Science Center and support group meetings were examined by M.S.L. or R.F.P. Dystonia was classified in accordance with established schemes $[1,3,24]$. Subjects with established diagnoses of DYT1 dystonia were not recruited into our study.

Clinical diagnoses for 1264 subjects interrogated with HRM appear in Table 1. Demographic information and dystonia distribution was not available for 96 DNA samples received from Athena Diagnostics, Inc. (Worcester, MA). The panel from Athena Diagnostics included 8 samples with confirmed DYT1 $\triangle$ GAG deletions and $88 \Delta$ GAGnegative samples associated with a clinical diagnosis of "dystonia."

\section{DNA}

DNA was extracted from peripheral blood leucocytes using Roche's DNA Isolation Kit for Mammalian Blood (Roche Applied Science, Indianapolis, IN). DNA quantity and quality were analyzed with a NanoDrop ND-100 spectrophotometer (NanoDrop Technologies LLC, Wilmington, DE), Quant-i $T^{\mathrm{TM}}$ PicoGreen ${ }^{\circledast}$ dsDNA Assay Kit (Invitrogen Inc. Carlsbad, CA) and agarose gel electrophoresis. High-quality DNA samples were diluted with PCR water to a concentration of $10 \mathrm{ng} / \mu \mathrm{l}$. Poor quality samples were rescued by whole genome amplification with the REPLI-g ${ }^{\circledR}$ Mini Kit from Qiagen (Valencia, CA). Samples that could not be rescued were not used for HRM and do not appear in Table 1.

\section{HRM}

Using Primer3 (frodo.wi.mit.edu), a pair of PCR primers was designed to cover the entire TOR1A Exon 5 coding sequence (forward: cagcaccttgtttcttcttcc, reverse: ccaactccaggcagtgactc). Another forward primer was synthesized for site-directed mutagenesis of Exon 5 to generate the c. $863 \mathrm{G}>\mathrm{A}$ mutation (aacagcacettgtttcttcttcccaggtggcttctggcacagcagcttaattgaccggaacctcattgattattttgttccettcctccccctggaatacaaacacctaaaaatgt gtatccgagtggaaatgcagtcccAaggctatga). To evaluate HRM results with amplicons of different sizes, a pair of previously-published primers was used to amplify the DYT1 $\triangle \mathrm{GAG}$ region of Exon 5 [13].

The LightCycler ${ }^{\circledR} 480$ Real-Time PCR system and High Resolution Master Mix from Roche Applied Science (Indianapolis, IN, USA) were used for HRM. The master mix contains the LightCycler 480 ResoLight Dye. The High Resolution Melting Master Mix is a ready-to-use hot-start mix designed for PCR amplification followed by HRM curve analysis for detection of sequence variants. ResoLight, a novel saturating DNA dye, was specifically designed for detection of sequence variations by differences in melting curves. ResoLight can be used at high concentrations without inhibiting PCR and its homogeneous staining of target sequences results in sharp melting signals. As the temperature of the solution is increased during HRM, the specific sequence of the amplicon (primarily GC content and length) determines the melting behavior. When the fluorescence signal is plotted against temperature, fluorescence intensity decreases as doublestranded DNA (dsDNA) becomes single stranded and ResoLight is released. Since melting point $\left(T_{M}\right)$ differences are often too small for reliable differentiation of amplicons, separation is achieved by signal normalization and temperature shifting (Fig 1a, c, e, and 1g). For normalization, the pre- and post-melt signals are set to uniform relative values. For temperature shifting, the temperature axes of the normalized melting curves are shifted to the point where the entirety of dsDNA is denatured. The LightCycler 480 Gene Scanning Software detects differences in melting curves and allocates samples to groups of the same sequence. Finally, difference plots are created by subtracting melting curves from a reference curve (Fig $1 \mathrm{~b}$, $\mathrm{d}, \mathrm{f}$, and $1 \mathrm{~h}$ ).

The HRM Master Mix contains FastStart Taq DNA polymerase, reaction buffer, a dNTP mix and ResoLight. HRM was optimized to detect and differentiate the $\Delta$ GAG and c. $863 \mathrm{G}>\mathrm{A}$ mutations by adjusting reaction conditions and the concentrations of template DNA, primers and $\mathrm{MgCl}_{2}$. To emulate the heterozygous state, a 1:1 mixture of normal DNA with c.863G $>$ A amplicons was utilized for these reactions. Then, to define sensitivity and sensitivity, HRM was performed with the collection of 96 samples from Athena Diagnostics that included 8 samples with confirmed DYT1 $\triangle$ GAG deletions and 88 additional samples with a clinical diagnosis of "dystonia." Optimized reactions were performed in 96-well plates (Roche Cata$\log \# 04729692001$ ) using 10-20 ng of template DNA, $1 \times$ HRM Master Mix, $2.5 \mathrm{mM} \mathrm{MgCl}_{2}$ and $200 \mathrm{nM}$ of each primer in a $20-\mu \mathrm{l}$ reaction volume. PCR cycling and HRM conditions were carried out as follows: $95^{\circ} \mathrm{C}$ for $10 \mathrm{~min}$; 45 cycles at $95^{\circ} \mathrm{C}$ for $10 \mathrm{~s}, 60^{\circ} \mathrm{C}$ for $15 \mathrm{~s}$, and $72^{\circ} \mathrm{C}$ for 15 $\mathrm{s} ; 95^{\circ} \mathrm{C}$ for $1 \mathrm{~min}, 40^{\circ} \mathrm{C}$ for $1 \mathrm{~min}$, and the final HRM temperature ramp from $70^{\circ} \mathrm{C}$ to $95^{\circ} \mathrm{C}$ rising at $0.1^{\circ} \mathrm{C} / \mathrm{s}$. All subject samples and negative controls were run in duplicate using 96-well plates.

With LightCycler 480 Gene Scanning Software, melting curves and difference plots were analyzed by three investigators (S.G., Y.Z., and M.S.L.) blinded to phenotype. All samples were unambiguously assigned to one of three genotypes (wild-type or normal, $\triangle \mathrm{GAG}$ deletion, or 
Table I: Clinical diagnoses and demographics

\begin{tabular}{|c|c|c|c|c|c|c|c|c|}
\hline \multirow[t]{2}{*}{ Clinical diagnosis } & \multirow{2}{*}{$\begin{array}{c}\text { Number (age of } \\
\text { onset) })^{\mathrm{a}}\end{array}$} & \multirow[t]{2}{*}{ Family historyb } & \multicolumn{2}{|c|}{ Gender } & \multicolumn{3}{|c|}{ Race/Ethnicity } & \multirow{2}{*}{$\begin{array}{c}\text { TORIA exon } 5 \\
\text { mutations }\end{array}$} \\
\hline & & & Male & Female & $\begin{array}{c}\text { Non-Jewish } \\
\text { Caucasian }\end{array}$ & Jewish & Other & \\
\hline Spasmodic dysphonia & $\begin{array}{c}422 \\
(45.0 \pm 15.7,7-84)\end{array}$ & $7.3 \%$ & 91 & 331 & 368 & 2 & 52 & I $\triangle \mathrm{GAG}$ \\
\hline Cervical dystonia & $\begin{array}{c}285 \\
(43.7 \pm 13.8,4-76)\end{array}$ & $8.4 \%$ & 71 & 214 & 268 & I & 16 & 0 \\
\hline Blepharospasm & $\begin{array}{c}67 \\
(54.4 \pm 10.1,20-73)\end{array}$ & $10.4 \%$ & 20 & 47 & 61 & 2 & 4 & 0 \\
\hline Writer's cramp & $\begin{array}{c}4 \mid \\
(35.3 \pm \mid 4.4,7-60)\end{array}$ & $7.3 \%$ & 17 & 24 & 35 & 0 & 6 & 0 \\
\hline $\begin{array}{l}\text { Oromandibular } \\
\text { dystonia }\end{array}$ & $\begin{array}{c}16 \\
(48.9 \pm 15.4,20-70)\end{array}$ & $6.3 \%$ & 3 & 13 & 13 & I & 2 & 0 \\
\hline $\begin{array}{l}\text { Other primary focal } \\
\text { dystonia }\end{array}$ & $\begin{array}{c}38 \\
(37.8 \pm 18.2,10-74)\end{array}$ & $5.3 \%$ & 14 & 24 & 34 & 0 & 4 & 0 \\
\hline Segmental dystonia & $\begin{array}{c}112 \\
(48.7 \pm 12.8,14-74)\end{array}$ & $13.4 \%$ & 39 & 73 & 101 & 0 & 11 & 0 \\
\hline Multifocal dystonia & $\begin{array}{c}16 \\
(30.0 \pm 15.9,7-67)\end{array}$ & $25.0 \%$ & 3 & 13 & 15 & 0 & 1 & I $\triangle \mathrm{GAG}$ \\
\hline Generalized dystonia & $\begin{array}{c}17 \\
(18.2 \pm 15.3,1-57)\end{array}$ & $0.0 \%$ & 7 & 10 & 17 & 0 & 0 & 0 \\
\hline Dystonia totals & $\begin{array}{c}1014 \\
(44.3 \pm 15.6,1-84)\end{array}$ & $8.6 \%$ & 265 & 749 & 912 & 6 & 96 & 2 GAG \\
\hline Parkinson's disease & $\begin{array}{c}42 \\
(63.0 \pm 12.5,28-82)\end{array}$ & NA & 19 & 23 & 39 & 0 & 3 & 0 \\
\hline Restless legs syndrome & $\begin{array}{c}31 \\
(40.6 \pm 18.3,8-66)\end{array}$ & NA & 12 & 19 & 29 & 0 & 2 & 0 \\
\hline Essential tremor & $\begin{array}{c}14 \\
(50.9 \pm I 5.4,30-70)\end{array}$ & NA & 9 & 5 & 13 & 0 & 1 & 0 \\
\hline $\begin{array}{l}\text { Other movement } \\
\text { disorders }\end{array}$ & $\begin{array}{c}13 \\
(49.8 \pm 17.3,27-7 \mid)\end{array}$ & NA & 9 & 4 & 12 & 0 & I & 0 \\
\hline $\begin{array}{l}\text { Neurologically-normal } \\
\text { controls }\end{array}$ & $\begin{array}{c}150 \\
(56.5 \pm 14.5,23-83)^{c}\end{array}$ & NA & 79 & 71 & 135 & 0 & 15 & 0 \\
\hline $\begin{array}{l}\Delta \text { GAG-negative } \\
\text { dystonia }\end{array}$ & $\begin{array}{c}88 \\
(\mathrm{NA})\end{array}$ & NA & NA & NA & NA & NA & NA & 0 \\
\hline$\triangle$ GAG DYTI dystonia & $\begin{array}{c}8 \\
(\mathrm{NA})\end{array}$ & NA & NA & NA & NA & NA & NA & $8 \triangle \mathrm{GAG}$ \\
\hline Grand totals & 1360 & & & & & & & $10 \triangle G A G$ \\
\hline $\begin{array}{l}\text { aMean }+/ \text { - standard erro } \\
\text { bFirst- or second-degree } \\
\text { cAge at study enrollmen } \\
\text { NA = not available or a }\end{array}$ & $\begin{array}{l}\text { range (yrs). } \\
\text { elative with dystonia. } \\
\text { licable. }\end{array}$ & & & & & & & \\
\hline
\end{tabular}


c.863G $>$ A mutation) by Gene Scanning Software. DNA from wells with abnormal melting curves was purified with the Qiagen QIAquick PCR Purification Kit. The $\triangle \mathrm{GAG}$ deletion and c.863G $>$ A mutations were confirmed by direct sequencing of purified PCR products in the forward and reverse directions using an ABI Prism 377 DNA Sequencer (Applied Biosystems, Foster City, CA, USA).

\section{Results HRM}

As seen in Fig $1 \mathrm{a}$ and $1 \mathrm{~b}$, all $8 \Delta \mathrm{GAG}$-positive samples were clearly differentiated from the $88 \Delta \mathrm{GAG}$-negative samples; amplicons containing the $\triangle \mathrm{GAG}$ mutation melted/denatured prior to the $\triangle$ GAG-negative samples. The $\triangle$ GAG-positive samples clustered together on the melting curves and difference plots with minimal sampleto-sample variation. Furthermore, segregation of $\triangle \mathrm{GAG}$ positive and $\triangle$ GAG-negative samples was maintained despite 25-fold variation in the concentrations of DNA templates from $0.1 \mathrm{ng} / \mu \mathrm{l}$ to $2.5 \mathrm{ng} / \mu \mathrm{l}$ (Fig $1 \mathrm{c}$ and $1 \mathrm{~d}$ ). No false positive or false negative samples were detected within this broad concentration range.

HRM robustly distinguished samples with either $\triangle \mathrm{GAG}$ deletions or $\mathrm{c} .863 \mathrm{G}>\mathrm{A}$ mutations from normals (Fig 1e1h). Diagnostic sensitivity and diagnostic specificity for $\triangle$ GAG deletion and c.863G $>$ A mutation were $100 \%$ with both primer pairs (Fig 1e-1h). As expected, the larger TOR1A Exon 5 amplicon (314 bp, Fig 1e and 1f) had a higher melting temperature $\left(\mathrm{T}_{\mathrm{M}}=83.2^{\circ} \mathrm{C}\right)$ than the smaller amplicon $\left(205 \mathrm{bp}, \mathrm{T}_{\mathrm{M}}=81.2^{\circ} \mathrm{C}\right.$ ) which was generated with previously published primers [13].

LightCycler $^{\circledR} 480$ HRM Master Mix (Catalog \#04909631001) was purchased for $\$ 400$ http:// www.roche-applied-science.com and contained reagents for 500 reactions (20 $\mu$ reaction volume, $\$ 0.80 /$ reaction). LightCycler $^{\circledR} 480$ Multiwell Plates 96, white with sealing foils (Catalog \# 04729692001), must be used for HRM and were purchased for $\$ 360 / 50$ plates ( $\$ 7.20 /$ plate). Excluding the costs of pipette tips and primers, 96 reactions were completed for $\$ 84.00$. On average, each plate was setup, run, and analyzed in 3 hrs.

\section{TORIA Exon 5 Mutations in Non-Generalized Primary Dystonia}

Two subjects (\#1 and \#2) with non-generalized primary dystonia were found to harbor the classic DYT1 $\triangle \mathrm{GAG}$ deletion in Exon 5 of TOR1A. No TOR1A Exon 5 mutations or variants were identified in the remaining 1012 subjects with dystonia or 250 controls. Subject \# 1 with the classic DYT1 $\triangle$ GAG mutation exhibited multifocal dystonia. She was a 48-yr-old non-Jewish Caucasian female with cervical dystonia, spasmodic dysphonia (adductor subtype), and writer's cramp. Cervical dystonia became manifest at 12 yrs of age whereas laryngeal involvement and writer's cramp became apparent at 39 and 45 yrs of age, respectively. She reported consistent benefit from injections of botulinum toxin type A for treatment of her laryngeal and cervical dystonia. Her mother had never been diagnosed with "dystonia" but reportedly exhibited action-induced "leg tremors." A maternal aunt (her mother's monozygotic twin) suffered from an undiagnosed voice disorder prior to her death. Subject \#1 had two siblings, both brothers. By report, one brother was neurologically normal. The second brother developed generalized dystonia at 9 years of age and died at 16 years of age with respiratory complications.

Subject \#2, also with the classic DYT1 $\triangle$ GAG mutation, was a 63-yr-old woman of Ashkenazi Jewish descent. She had spasmodic dysphonia (adductor subtype) that became manifest at 19 years of age. Injections of botulinum toxin type A achieved consistently excellent results over a period of 12 yrs. Subject \#2 also exhibited a bilateral upper extremity action tremor ( $<2 \mathrm{~cm}$ excursions). She had one child who was neurologically normal. Her mother and maternal grandmother had received diagnoses of "essential tremor." None of her family members were available for neurological examination.

\section{Discussion}

In 2000, Bressman and colleagues published diagnostic testing guidelines for the DYT1 GAG deletion [25] and recommended DYT1 $\triangle \mathrm{GAG}$ testing in conjunction with genetic counseling for subjects displaying primary dystonia with onset prior to 26 yrs of age. Testing may be warranted in subjects with onset after age 26 if they have an affected relative with early-onset primary dystonia [25]. Our results are entirely consistent with those guidelines. Although de novo $\triangle \mathrm{GAG}$ mutations of TOR1A Exon 5 have been described [26,27], our findings indicate that they must be extraordinarily rare in non-generalized primary dystonia in the United States. Furthermore, we have shown that other TOR1A Exon 5 variants, including the recently described c.863G $>A$ missense mutation, must also be rare in subjects with non-generalized primary dystonia.

As outlined in Table 2, the classic DYT1 $\triangle$ GAG mutation is uncommon in non-generalized primary dystonia and quite rare in late-onset primary dystonia. The typical DYT1 phenotype is characterized by early-onset in a limb, most commonly a leg, with spread to other limbs and the trunk over several years. Writer's cramp or more extensive upper limb dystonia without task-specificity is the most common presentation of adolescent- or late-onset primary dystonia due to the DYT1 $\triangle$ GAG mutation and most of these subjects will have a positive family history of dystonia [19]. However, DYT1 dystonia is phenotypically 

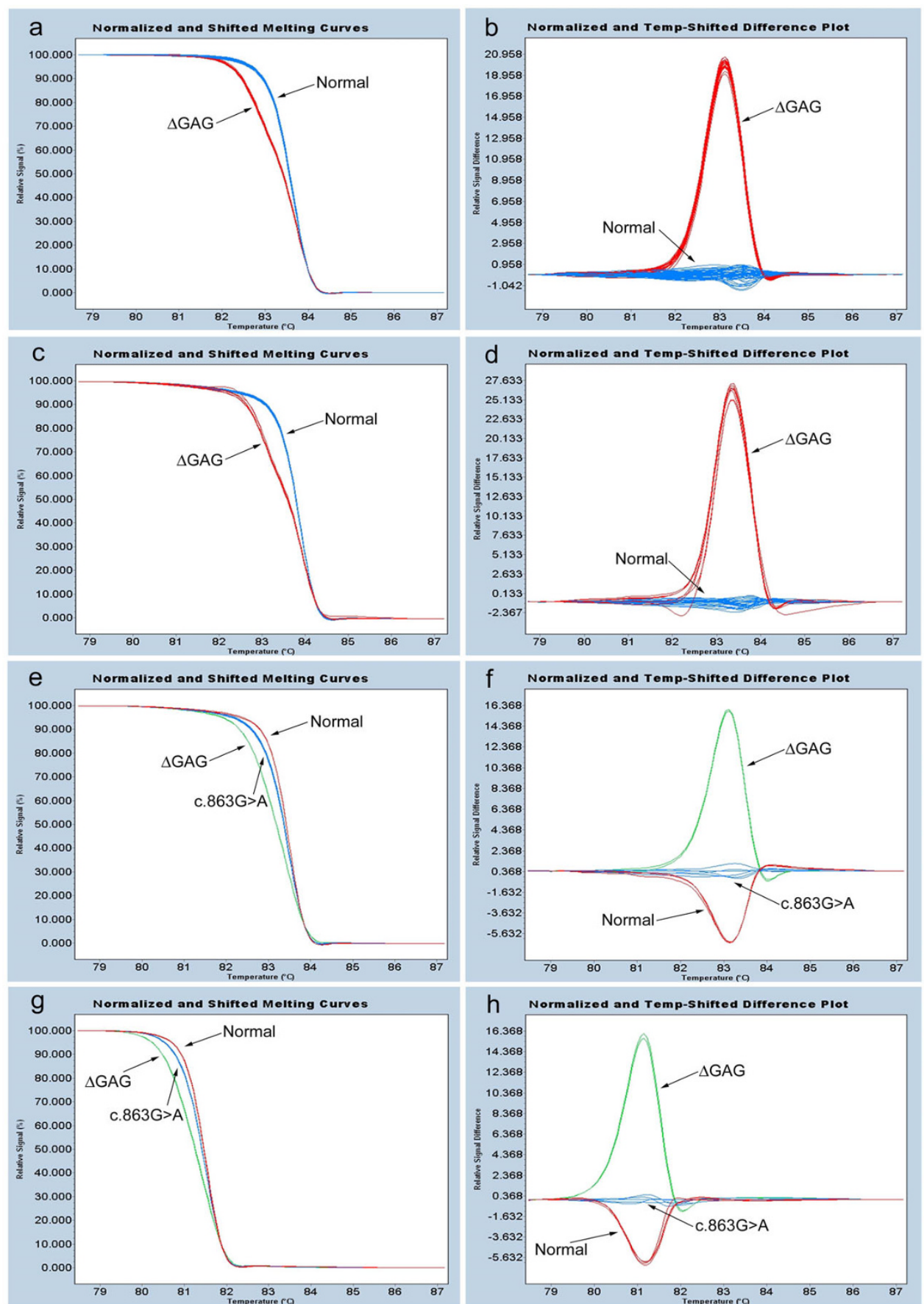

\section{Figure I}

HRM results of TORIA Exon 5 coding region. Normalized and temperature-shifted melting curves (a) and difference plots (b) for $8 \Delta G A G$-positive (red) and $88 \Delta G A G$-negative (blue) samples. Normalized and temperature-shifted melting curves (c) and difference plots (d) for one $\triangle \mathrm{GAG}$-positive (red) and five $\triangle \mathrm{GAG}$-negative (blue) samples with different concentrations of DNA template $(0.1 \mathrm{ng} / \mu \mathrm{l}, 0.25 \mathrm{ng} / \mu \mathrm{l}, 0.5 \mathrm{ng} / \mu \mathrm{l}, \mathrm{I} \mathrm{ng} / \mu \mathrm{l}$, and $2.5 \mathrm{ng} / \mu \mathrm{l}$; each in duplicate). Normalized and temperature-shifted melting curves (e) and difference plots (f) for $\triangle \mathrm{GAG}$-positive (green; one sample, in duplicate), $\triangle \mathrm{GAG}$-negative (red; three samples, each in duplicate) and c.863G>A mutation (blue; I:I mixtures of template DNA from normals with c.863G>A amplicons) 314 bp amplicons. Normalized and temperature-shifted melting curves ( $g$ ) and difference plots (h) for $\Delta G A G$-positive (green; one sample, in duplicate), $\triangle$ GAG-negative (red; three samples, each in duplicate) and c.863G $>$ A mutation (blue; I:I mixtures of template DNA from normals with c.863G>A amplicons) 205 bp amplicons. 
Table 2: DYTI mutations in non-generalized primary dystonia

\begin{tabular}{|c|c|c|c|}
\hline Reference & $\begin{array}{l}\text { Number of subjects with non- } \\
\text { generalized primary dystonia }\end{array}$ & $\begin{array}{c}\text { Number with GAG } \\
\text { mutations }\end{array}$ & $\begin{array}{l}\text { Phenotypic description of } \\
\text { GAG-positive subjects }\end{array}$ \\
\hline Valente et al. (1998) [15] & $\begin{array}{l}108 \text { (Europe) } \\
S=48, F=60\end{array}$ & $3(2.8 \%)$ & $\begin{array}{l}\text { \#I: S(arms), early-onset, } \mathrm{FH}+\text {, Jewish } \\
\# 2 \text { : } \mathrm{F}(\mathrm{arm}) \text {, early-onset, } \mathrm{FH}-\text {, Jewish } \\
\# 3 \text { : } \mathrm{F}(\mathrm{arm}) \text {, early-onset, } \mathrm{FH}+\end{array}$ \\
\hline Klein et al. (1999) [37] & $\begin{array}{l}300 \\
\text { (United States, Germany, Italy; late- } \\
\text { onset \& FH+) } \\
S=7, F=293\end{array}$ & $3(1.0 \%)$ & $\begin{array}{l}\# 1: \text { S(both legs \& one arm), late- } \\
\text { onset, FH+ } \\
\# 2: \text { F(cranial), late-onset, } \mathrm{FH}+ \\
\# 3: \mathrm{F}(\mathrm{NA}) \text {, late-onset, } \mathrm{FH}+\text {, Jewish }\end{array}$ \\
\hline Brassat et al. (2000) [39] & $\begin{array}{l}90 \text { (France, } \mathrm{FH}-\text { ) } \\
\mathrm{S}=2 \mathrm{I}, \mathrm{F}=69\end{array}$ & $I(I .1 \%)$ & \#I: S(leg \& trunk), early-onset, FH- \\
\hline Kamm et al. (2000) [40] & $\begin{array}{l}44 \text { (Germany) } \\
F=44 \text { (writer's cramp) }\end{array}$ & $0(0.0 \%)$ & NA \\
\hline Friedman et al. (2000) [4I] & $\begin{array}{l}\text { I8 (United States) } \\
\mathrm{F}=18 \text { (musicians) }\end{array}$ & $0(0.0 \%)$ & NA \\
\hline Major et al. (200I) [42] & $\begin{array}{l}38 \text { (Serbia) } \\
M=1, S=22, F=15\end{array}$ & $2(5.3 \%)$ & $\begin{array}{l}\text { \#I: S(both arms), early-onset, FH- } \\
\text { \#2: M(right arm \& left leg), early- } \\
\text { onset, FH- }\end{array}$ \\
\hline Matsumoto et al. (200I) [43] & $\begin{array}{l}173 \text { (Japan) } \\
M=4, S=29, F=144,\end{array}$ & $3(1.7 \%)$ & $\begin{array}{l}\# \mathrm{I}: \mathrm{F}(\mathrm{arm}) \text {, early-onset, } \mathrm{FH}+ \\
\# 2: \mathrm{F}(\mathrm{arm}) \text {, early-onset, } \mathrm{FH}+ \\
\# 3: \mathrm{F}(\mathrm{leg}) \text {, late-onset, } \mathrm{FH}+\end{array}$ \\
\hline Maniak et al. (2003) [8] & $\begin{array}{l}130 \text { (Germany) } \\
S=10, F=120\end{array}$ & $0(0.0 \%)$ & NA \\
\hline Grundmann et al. (2003)[17] & $\begin{array}{l}244 \text { (Germany) } \\
M=11, S=46, F=187\end{array}$ & $4(1.6 \%)$ & $\begin{array}{l}\text { \#I: M(both legs \& right arm), early- } \\
\text { onset, FH- } \\
\text { \#2: M(both arms \& cranial), late- } \\
\text { onset, FH+ } \\
\text { \#3: S(both arms), early-onset, FH+ } \\
\text { \#4: S(both arms), early-onset, FH- }\end{array}$ \\
\hline Kabakci et al. (2004) [18] & $\begin{array}{l}126 \text { (Germany) } \\
F+S=126\end{array}$ & $0(0 \%)$ & NA \\
\hline Im et al. (2004) [44] & $\begin{array}{l}155 \text { (Korea) } \\
S=21, F=134\end{array}$ & $2(1.3 \%)$ & $\begin{array}{l}\# 1: \text { S(arm \& shoulder), early-onset, } \\
\mathrm{FH}+ \\
\# 2 \text { : S(arm \& neck), early-onset, FH- }\end{array}$ \\
\hline Dhaenens et al. (2005) [45] & $\begin{array}{l}150 \text { (France) } \\
\mathrm{F}=150\end{array}$ & I (0.7\%) & \#I: F(arm), onset?, $\mathrm{FH}+$ \\
\hline Lin et al. (2006) [46] & $\begin{array}{l}186 \text { (Taiwan) } \\
M=3, S=47, F=136\end{array}$ & $2(1.1 \%)$ & $\begin{array}{l}\text { \#I: } \mathrm{F}(\mathrm{leg}), \text { early-onset, } \mathrm{FH}+ \\
\# 2: \text { (neck \& trunk), late-onset, } \mathrm{FH}+\end{array}$ \\
\hline Jamora et al. (2006) [47] & $\begin{array}{l}54 \text { (Singapore) } \\
M=I, S=I I, F=4 I\end{array}$ & $0(0.0 \%)$ & NA \\
\hline Naiya et al. (2006) [48] & $\begin{array}{l}150 \text { (India) } \\
F=138, S=12\end{array}$ & $0(0 \%)$ & NA \\
\hline Gajos et al. (2007) [3।] & $\begin{array}{l}48 \text { (Poland) } \\
G+S+F=48\end{array}$ & $F=2(N A)$ & $\begin{array}{l}\text { \#I: } \mathrm{F}(\mathrm{arm}) \text {, late-onset, } \mathrm{FH}+ \\
\# 2: \mathrm{F}(\mathrm{arm}) \text {, early-onset, } \mathrm{FH}+\end{array}$ \\
\hline
\end{tabular}

G, generalized dystonia; M, multifocal dystonia; S, segmental dystonia; F, focal dystonia; FH, family history of dystonia; and NA, not applicable. 
heterogeneous with oftentimes striking intrafamilial and interfamilial variability [28-31]. Indeed, our subject \#1 had childhood-onset cervical dystonia with much later development of laryngeal dystonia and writer's cramp, whereas subject \#2 manifested dystonia with isolated laryngeal involvement for over 40 yrs. Other remarkable phenotypes described in the literature include onset of focal dystonia at 64 yrs, status dystonicus, and late-onset dystonia precipitated by exposure to a neuroleptic $[29,30]$.

In comparison with several of the studies listed in Table 2, the percentage of $\triangle \mathrm{GAG}$ mutations was relatively low in our cohort of subjects with non-generalized dystonia. Approximately, $90 \%$ of our patients with primary dystonia were non-Jewish Caucasians born in the United States; only 6 Jewish subjects were screened for TOR1A Exon 5 mutations. Since the carrier frequency of the classic DYT1 $\triangle$ GAG mutation is estimated at $1: 1000-1: 3000$ in Ashkenazi Jews [32] and less than 1:30,000 in non-Jews [33], inclusion of additional Jewish subjects may have increased our percentage of $\triangle \mathrm{GAG}$ cases.

Our study was limited to interrogation of Exon 5 of TOR1A and does not exclude a role for TOR1A mutations and/or variants in the etiopathogenesis of late-onset primary dystonia. Single nucleotide polymorphisms (SNPs) within or in close proximity to the 3' UTR of TOR1A may be associated with primary focal dystonia [34-36]. Mutations in Exons 1-4 and associations between dystonia phenotypes and TOR1A copy number variants and single nucleotide polymorphisms must be interrogated in future studies.

Previous studies of primary dystonia have employed a wide variety of methods for detection of TOR1A mutations [13,21,37-49]. For large cohorts, direct sequencing of each sample is expensive, labor intensive, and inefficient. Similarly, previously employed techniques such as PCR-based polyacrylamide gel electrophoresis (PAGE) with silver staining [37], restriction fragment length polymorphism (RFLP) analysis with restriction enzyme BseR1 [38-48] and SSCP (single-strand conformation polymorphism) analysis $[13,21]$, are slow, requiring multiple steps including gel electrophoresis. Although not gel-dependent, denaturing high-performance liquid chromatography (DHPLC) also requires post-PCR handling which is laborintensive and associated with the risk of well-to-well cross contamination [49].

HRM has recently been introduced as a screening method for mutation detection. HRM is a closed-tube method that can be performed in a rapid, economical, reliable, and high-throughput fashion. In a comparative study, Chou and colleagues showed that HRM is superior to DHPLC
[50]. HRM has been utilized for the detection of germline and somatic mutations as well as SNP genotyping with high sensitivity and specificity [23,51-54]. Other HRM applications include microsatellite analysis, screening for loss of heterozygosity, and DNA methylation analysis.

The utility and efficiency of HRM can be maximized by careful experimental design. In our study, a single pair of primers was designed to cover the entire coding region of TOR1A Exon 5 and generated a 314 bp amplicon. Theoretically, differentiation of samples carrying a sequence variation is better with shorter amplicons. In general, amplicons from 50 to 250 bp are ideal for HRM, particularly when employed for SNP and homozygous mutation analysis. However, 100\% sensitivity and specificity has been observed with amplicons larger than 600 bp [55]. Thus, the clear separation of $314 \mathrm{bp}$ amplicons harboring heterozygous $\triangle \mathrm{GAG}$ and c.863G>A mutations was not unexpected.

HRM offers additional advantages over older screening techniques. First, amplicons of interest only require purification prior to follow-up sequencing. There is no need to PCR amplify DNA templates. Second, HRM robustly differentiates genotypes despite moderate differences in well-to-well concentrations of DNA templates. Lastly, Roche's LightCycler ${ }^{\circledR} 480$ Real-Time PCR system offers 384-well plate capabilities which, when coupled with a robotic workstation, permits completion of very large projects (>10,000 samples) in a single week. Clearly, HRM is well-suited for many candidate gene and SNPassociation studies of dystonia and other neurological disorders.

\section{Conclusion}

In conclusion, we have developed a fast, efficient and reliable screening method for known mutations $(\triangle \mathrm{GAG}$ and c. $863 \mathrm{G}>\mathrm{A}$ ) within the coding region of TOR1A Exon 5 using HRM. HRM showed $100 \%$ diagnostic sensitivity and specificity. In a large cohort of patients with non-generalized primary dystonia in the US, TOR1A Exon 5 mutations were very uncommon; only two classic DYT1 $\triangle \mathrm{GAG}$ and no c. $863 \mathrm{G}>\mathrm{A}$ mutations were identified. HRM may be applicable to high-throughput mutation detection in other movement and general neurological disorders.

\section{Competing interests}

The authors declare that they have no competing interests.

\section{Authors' contributions}

MSL designed the study. JX, SG and YZ extracted DNA from blood samples. JX and MSL optimized and implemented the HRM protocol and analyzed HRM data. RWB, JSP, BAR, SDT, MK, RP, AB, ZKW, RJU, PH, DKS, DT, DDT, $\mathrm{KPF}, \mathrm{RFP}$ and MSL examined research subjects. SDB pro- 
vided DNA from subjects with a clinical diagnosis of dystonia. JX and MSL drafted the manuscript. All authors read and approved the final manuscript.

\section{Acknowledgements}

This study was supported by the Neuroscience Institute at the University of Tennessee Health Science Center (M.S.L.), Dystonia Medical Research Foundation (M.S.L.) and NIH National Institute of Neurological Disease and Stroke grant ROINS048458 (M.S.L.). At Washington University School of Medicine, work was supported by the NIH National Institute of Neurological Disease and Stroke grants P30NS05710 (Neuroscience Blueprint Grant) and Clinical Sciences Translation Award RR024992, the American Parkinson's Disease Association (APDA) Advanced Research Center, the Greater St. Louis Chapter of the APDA, the Barnes-Jewish Hospital Foundation (Jack Buck Fund for PD Research and the Elliot H. Stein Family Fund), the Missouri Chapter of the Dystonia Research Foundation and the Murphy Fund. At Mayo Clinic Jacksonville, work was supported by the NIH National Institute of Neurological Disease and Stroke Morris K. Udall Center of Excellence for Parkinson Disease Research grant (P50-NS40256). At the Parkinson's \& Movement Disorder Institute, work was supported by the Long Beach Memorial Foundation, Orange Coast Memorial Foundation, and the Parkinson's \& Movement Disorder Foundation.

We gratefully acknowledge the assistance of C. Lohnes, J. Dennhardt, A. Fitzgerald, E. Heintzen, L. Carpenter, C. Keppel, J. Hartlein, T. Pretorius, A. Strongosky, J. Searcy, H. Lam, and C. Lim.

\section{References}

I. Fahn S, Marsden CD, Calne DB: Classification and investigation of dystonia. In Movement disorders 2 Edited by: Marsden CD, Fahn S. London: Butterworths; 1987:332-358.

2. Fahn S: Concept and classification of dystonia. Adv Neurol 1988, 50:1-8.

3. Fahn S, Bressman SB, Marsden CD: Classification of dystonia. Adv Neurol 1998, 78:I-I0.

4. Defazio G, Abbruzzese G, Livrea P, Berardelli A: Epidemiology of primary dystonia. Lancet Neurol 2004, 3:673-678.

5. Duane DD: Spasmodic torticollis: clinical and biologic features and their implications for focal dystonia. Adv Neurol 1988, 50:473-492.

6. Grandas F, Elston J, Quinn N, Marsden CD: Blepharospasm: a review of 264 patients. J Neurol Neurosurg Psychiatry 1988, $5 \mathrm{I}: 767-772$

7. Chan J, Brin MF, Fahn S: Idiopathic cervical dystonia: clinical characteristics. Mov Disord 1991, 6:1 19-126.

8. Maniak S, Sieberer M, Hagenah J, Klein C, Vieregge P: Focal and segmental primary dystonia in north-western Germany - a clinico-genetic study. Acta Neurol Scand 2003, 107:228-232.

9. Defazio G, Martino D, Aniello MS, Masi G, Abbruzzese G, Lamberti S, Valente EM, Brancati F, Livrea P, Berardelli A: A family study on primary blepharospasm. I Neurol Neurosurg Psychiatry 2006, 77:252-254.

10. Grundmann K, Laubis-Herrmann U, Dressler D, Vollmer-Haase J, Bauer P, Stuhrmann M, Schulte T, Schöls L, Topka H, Riess O: Lack of mutations in the epsilon-sarcoglycan gene in patients with different subtypes of primary dystonias. Mov Disord 2004, 19:1294-1297.

II. Brashear A, Dobyns WB, de Carvalho Aguiar P, Borg M, Frijns CJ, Gollamudi S, Green A, Guimaraes J, Haake BC, Klein C, Linazasoro G, Münchau A, Raymond D, Riley D, Saunders-Pullman R, Tijssen MA, Webb D, Zaremba J, Bressman SB, Ozelius LJ): The phenotypic spectrum of rapid-onset dystonia-parkinsonism (RDP) and mutations in the ATPIA3 gene. Brain 2007, I30:828-835.

12. Roze E, Apartis E, Clot F, Dorison N, Thobois S, Guyant-Marechal L, Tranchant C, Damier P, Doummar D, Bahi-Buisson N, André-Obadia $N$, Maltete $D$, Echaniz-Laguna $A$, Pereon $Y$, Beaugendre $Y$, Dupont $S$, De Greslan T, Jedynak CP, Ponsot G, Dussaule JC, Brice A, Dürr A, Vidailhet M: Myoclonus-dystonia: clinical and electrophysio- logic pattern related to SGCE mutations. Neurology 2008, 70:1010-1016.

13. Ozelius LJ, Hewett JW, Page CE, Bressman SB, Kramer PL, Shalish C, de Leon D, Brin MF, Raymond D, Corey DP, Fahn S, Risch NJ, Buckler AJ, Gusella JF, Breakefield XO: The early-onset torsion dystonia gene (DYTI) encodes an ATP-binding protein. Nat Genet 1997, 17:40-48.

14. Gasser T, Windgassen K, Bereznai B, Kabus C, Ludolph AC: Phenotypic expression of the DYTI mutation: a family with writer's cramp of juvenile onset. Ann Neurol 1998, 44: I 26-128.

15. Valente EM, Warner TT, Jarman PR, Mathen D, Fletcher NA, Marsden $C D$, Bhatia KP, Wood NW: The role of DYTI in primary torsion dystonia in Europe. Brain 1998, I 2 I (Pt I2):2335-2339.

16. O'Riordan S, Cockburn D, Barton D, Lynch T, Hutchinson M: Primary torsion dystonia due to the Tor IA GAG deletion in an Irish family. Ir J Med Sci 2002, I 7 I:31-32.

17. Grundmann K, Laubis-Herrmann U, Bauer I, Dressler D, VollmerHaase J, Bauer P, Stuhrmann M, Schulte T, Schöls L, Topka H, Riess $O$ : Frequency and phenotypic variability of the GAG deletion of the DYTI gene in an unselected group of patients with dystonia. Arch Neurol 2003, 60:1266-1270.

18. Kabakci K, Hedrich K, Leung JC, Mitterer M, Vieregge P, Lencer R, Hagenah J, Garrels J, Witt K, Klostermann F, Svetel M, Friedman J, Kostic V, Bressman SB, Breakefield XO, Ozelius LJ, Pramstaller PP, Klein C: Mutations in DYTI: extension of the phenotypic and mutational spectrum. Neurology 2004, 62:395-400.

19. Gambarin M, Valente EM, Liberini P, Barrano G, Bonizzato A, Padovani A, Moretto G, Fiorio M, Dallapiccola B, Smania N, Fiaschi A, Tinazzi M: Atypical phenotypes and clinical variability in a large Italian family with DYTI-primary torsion dystonia. Mov Disord 2006, 21 : 1 782-1784.

20. Zirn B, Grundmann K, Huppke P, Puthenparampil J, Wolburg H, Riess O, Muller U: Novel TORIA mutation p.Arg288GIn in earlyonset dystonia (DYTI). J Neurol Neurosurg Psychiatry 2008, 79:1327-1330.

21. Leung JC, Klein C, Friedman J, Vieregge P, Jacobs H, Doheny D, Kamm C, DeLeon D, Pramstaller PP, Penney JB, Eisengart M, Jankovic J, Gasser T, Bressman SB, Corey DP, Kramer P, Brin MF, Ozelius LJ, Breakefield XO: Novel mutation in the TORIA (DYTI) gene in atypical early onset dystonia and polymorphisms in dystonia and early onset parkinsonism. Neurogenetics 200I, 3:133-143.

22. Klein C, Liu L, Doheny D, Kock N, Müller B, de Carvalho Aguiar P, Leung J, de Leon D, Bressman SB, Silverman J, Smith C, Danisi F, Morrison C, Walker RH, Velickovic M, Schwinger E, Kramer PL, Breakefield $X O$, Brin MF, Ozelius LJ: Epsilon-sarcoglycan mutations found in combination with other dystonia gene mutations. Ann Neurol 2002, 52:675-679.

23. Wittwer CT, Reed GH, Gundry CN, Vandersteen JG, Pryor RJ: High-resolution genotyping by amplicon melting analysis using LCGreen. Clin Chem 2003, 49:853-60.

24. Bressman SB: Dystonia genotypes, phenotypes, and classification. Adv Neurol 2004, 94: I0I-I07.

25. Bressman SB, Sabatti C, Raymond D, de Leon D, Klein C, Kramer PL, Brin MF, Fahn S, Breakefield X, Ozelius LJ, Risch NJ: The DYTI phenotype and guidelines for diagnostic testing. Neurology 2000, 54: 1746-1752.

26. Klein C, Brin MF, de Leon D, Limborska SA, Ivanova-Smolenskaya IA, Bressman SB, Friedman A, Markova ED, Risch NJ, Breakefield XO, Ozelius LJ: De novo mutations (GAG deletion) in the DYTI gene in two non-Jewish patients with early-onset dystonia. Hum Mol Genet 1998, 7:1133-1136.

27. Hjermind LE, Werdelin LM, Sorensen SA: Inherited and de novo mutations in sporadic cases of DYTI-dystonia. Eur J Hum Genet 2002, 10:213-216.

28. Leube B, Kessler KR, Ferbert A, Ebke M, Schwendemann G, Erbguth F, Benecke R, Auburger G: Phenotypic variability of the DYTI mutation in German dystonia patients. Acta Neurol Scand 1999, 99:248-251.

29. Opal P, Tintner R, Jankovic J, Leung J, Breakefield XO, Friedman J, Ozelius L: Intrafamilial phenotypic variability of the DYTI dystonia: from asymptomatic TORIA gene carrier status to dystonic storm. Mov Disord 2002, I 7:339-345.

30. Edwards M, Wood N, Bhatia K: Unusual phenotypes in DYTI dystonia: a report of five cases and a review of the literature. Mov Disord 2003, 18:706-7II. 
31. Gajos A, Piaskowski S, Slawek J, Ochudło S, Opala G, Łobińska A, Honczarenko K, Budrewicz S, Koszewicz M, Pełszyńska B, Liberski PP, Bogucki A: Phenotype of the DYTI mutation in the TORIA gene in a Polish population of patients with dystonia. A preliminary report. Neurol Neurochir Pol 2007, 4I:487-494.

32. Risch N, de Leon D, Ozelius L, Kramer P, Almasy L, Singer B, Fahn S, Breakefield X, Bressman S: Genetic analysis of idiopathic torsion dystonia in Ashkenazi Jews and their recent descent from a small founder population. Nat Genet 1995, 9:I52-I59.

33. Frédéric M, Lucarz E, Monino C, Saquet C, Thorel D, Claustres M, Tuffery-Giraud S, Collod-Béroud G: First determination of the incidence of the unique TORIA gene mutation, c.907delGAG, in a Mediterranean population. Mov Disord 2007, 22:884-888.

34. Clarimon J, Asgeirsson $\mathrm{H}$, Singleton $\mathrm{A}$, Jakobsson $\mathrm{F}$, Hjaltason $\mathrm{H}$, Hardy J, Sveinbjornsdottir S: TorsinA haplotype predisposes to idiopathic dystonia. Ann Neurol 2005, 57:765-767.

35. Kamm C, Asmus F, Mueller J, Mayer P, Sharma M, Muller UJ, Beckert S, Ehling R, Illig T, Wichmann HE, Poewe W, Mueller JC, Gasser T: Strong genetic evidence for association of TORIA/TOR IB with idiopathic dystonia. Neurology 2006, 67:1857-1859.

36. Hague S, Klaffke S, Clarimon J, Hemmer B, Singleton A, Kupsch A, Bandmann O: Lack of association with torsinA haplotype in German patients with sporadic dystonia. Neurology 2006, 66:95I-952.

37. Klein C, Friedman J, Bressman S, Vieregge P, Brin MF, Pramstaller PP, De Leon D, Hagenah J, Sieberer M, Fleet C, Kiely R, Xin W, Breakefield XO, Ozelius LJ, Sims KB: Genetic testing for early-onset torsion dystonia (DYTI): introduction of a simple screening method, experiences from testing of a large patient cohort, and ethical aspects. Genet Test 1999, 3:323-328.

38. Kamm C, Castelon-Konkiewitz E, Naumann M, Heinen F, Brack M, Nebe A, Ceballos-Baumann A, Gasser T: GAG deletion in the DYTI gene in early limb-onset idiopathic torsion dystonia in Germany. Mov Disord 1999, 14:68I-683.

39. Brassat D, Camuzat A, Vidailhet M, Feki I, Jedynak P, Klap P, Agid Y, Dürr A, Brice A: Frequency of the DYTI mutation in primary torsion dystonia without family history. Arch Neurol 2000, 57:333-335.

40. Kamm C, Naumann M, Mueller J, Mai N, Riedel L, Wissel J, Gasser T: The DYT I GAG deletion is infrequent in sporadic and familial writer's cramp. Mov Disord 2000, I5:|238-|24|.

4I. Friedman JR, Klein C, Leung J, Woodward H, Ozelius LJ, Breakefield $X O$, Charness ME: The GAG deletion of the DYTI gene is infrequent in musicians with focal dystonia. Neurology 2000 55:14|7-14|8.

42. Major T, Svetel M, Romac S, Kostiæ VS: DYTI mutation in primary torsion dystonia in a Serbian population. J Neurol 200I, 248:940-943.

43. Matsumoto S, Nishimura M, Kaji R, Sakamoto T, Mezaki T, Shimazu $\mathrm{H}$, Murase N, Shibasaki H: DYTI mutation in Japanese patients with primary torsion dystonia. Neuroreport 200I, I 2:793-795.

44. Im JH, Ahn TB, Kim KB, Ko SB, Jeon BS: DYTI mutation in Korean primary dystonia patients. Parkinsonism Relat Disord 2004, 10:42I-423.

45. Dhaenens $C M$, Krystkowiak $P$, Douay $X$, Charpentier $P$, Bele $S$, Destée $A$, Sablonnière $B$ : Clinical and genetic evaluation in a French population presenting with primary focal dystonia. Mov Disord 2005, 20:822-825.

46. Lin YW, Chang HC, Chou YH, Chen RS, Hsu WC, Wu WS, Weng YH, Lu CS: DYT I mutation in a cohort of Taiwanese primary dystonias. Parkinsonism Relat Disord 2006, I 2:15-19.

47. Jamora RD, Tan EK, Liu CP, Kathirvel P, Burgunder JM, Tan LC: DYT I mutations amongst adult primary dystonia patients in Singapore with review of literature comparing East and West. J Neurol Sci 2006, 247:35-37.

48. Naiya T, Biswas A, Neogi R, Datta S, Misra AK, Das SK, Ray K, Ray J: Clinical characterization and evaluation of DYTI gene in Indian primary dystonia patients. Acta Neurol Scand 2006 , I | 4:210-2I5.

49. Yang JF, Li JY, Li YJ, Wu T, Zhang YL, Chen B: DYTI mutations amongst early onset primary dystonia patients in China. Chin Med Sci J 2008, 23:38-43.

50. Chou LS, Lyon E, Wittwer CT: A comparison of high-resolution melting analysis with denaturing high-performance liquid chromatography for mutation scanning: cystic fibrosis trans- membrane conductance regulator gene as a model. Am J Clin Pathol 2005, 124:330-338.

5I. Reed GH, Kent JO, Wittwer CT: High-resolution DNA melting analysis for simple and efficient molecular diagnostics. Pharmacogenomics 2007, 8:597-608.

52. Montgomery J, Wittwer CT, Kent JO, Zhou L: Scanning the cystic fibrosis transmembrane conductance regulator gene using high-resolution DNA melting analysis. Clin Chem 2007, 53:189|-1898.

53. Kennerson ML, Warburton T, Nelis E, Brewer M, Polly P, De Jonghe $P$, Timmerman V, Nicholson GA: Mutation scanning the GJB I gene with high-resolution melting analysis: implications for mutation scanning of genes for Charcot-Marie-Tooth disease. Clin Chem 2007, 53:349-352.

54. De Leeneer K, Coene I, Poppe B, De Paepe A, Claes K: Rapid and sensitive detection of BRCAI/2 mutations in a diagnostic setting: comparison of two high-resolution melting platforms. Clin Chem 2008, 54:982-989.

55. Reed GH, Wittwer CT: Sensitivity and specificity of singlenucleotide polymorphism scanning by high-resolution melting analysis. Clin Chem 2004, 50:1748-1754.

\section{Pre-publication history}

The pre-publication history for this paper can be accessed here:

http://www.biomedcentral.com/1471-2350/10/24/pre pub
Publish with Bio Med Central and every scientist can read your work free of charge

"BioMed Central will be the most significant development for disseminating the results of biomedical research in our lifetime. "

Sir Paul Nurse, Cancer Research UK

Your research papers will be:

- available free of charge to the entire biomedical community

- peer reviewed and published immediately upon acceptance

- cited in PubMed and archived on PubMed Central

- yours - you keep the copyright
BioMedcentral 